Prepared in cooperation with the U.S. Army Corps of Engineers, Portland District

Water Temperature Effects from Simulated Changes to Dam Operations and Structures in the Middle and South Santiam Rivers, Oregon

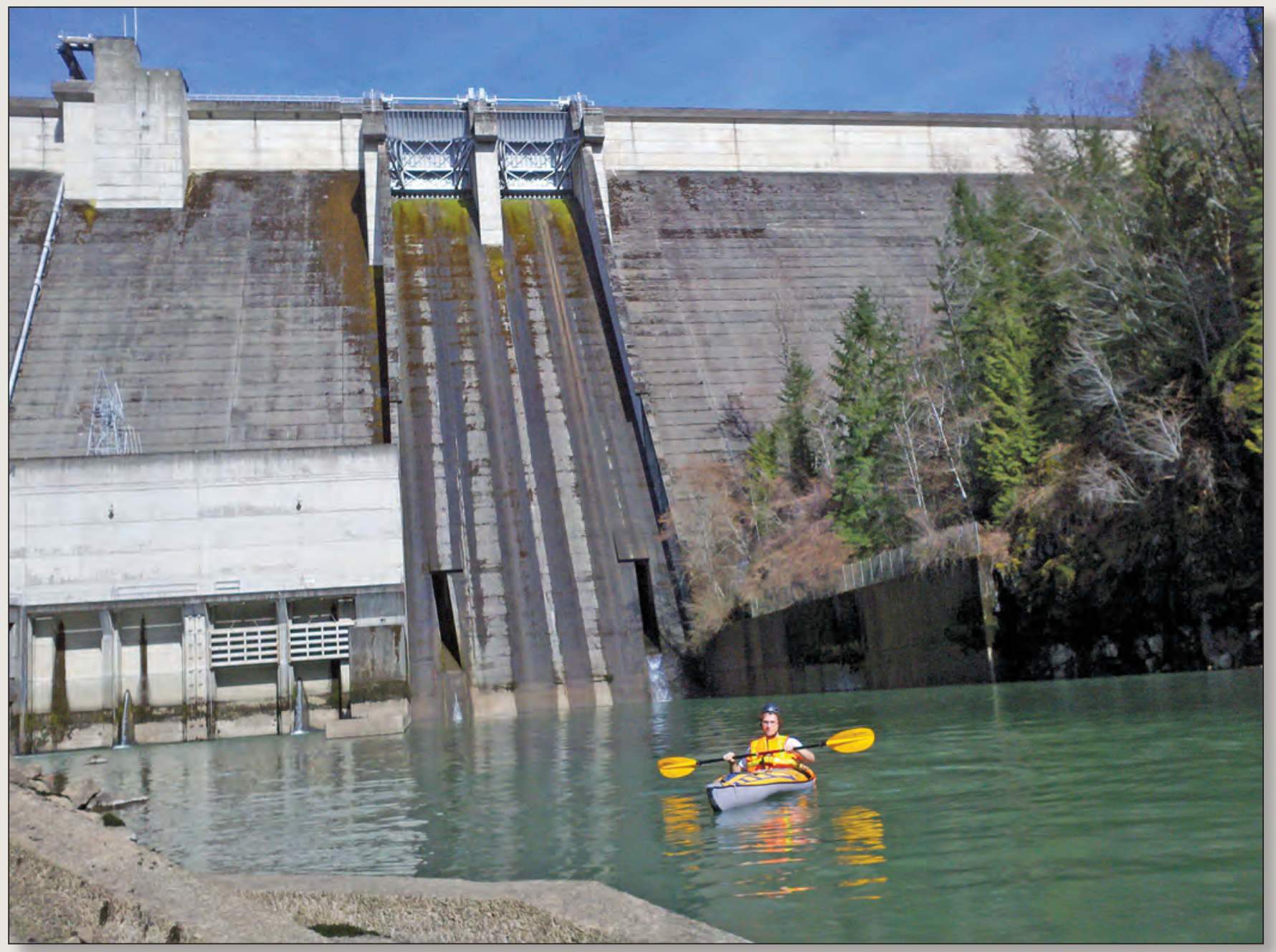

Open-File Report 2017-1063 
Cover: Photograph showing U.S. Geological Survey hydrologic technician taking cross-sectional temperature measurements at USGS streamgage 14186200 on the Middle Santiam River looking upstream at Green Peter Dam, Oregon, March 7, 2012. Photograph by Oregon Water Science Center staff, U.S. Geological Survey. 


\section{Water Temperature Effects from Simulated Changes to Dam Operations and Structures in the Middle and South Santiam Rivers, Oregon}

By Norman L. Buccola

Prepared in cooperation with the U.S. Army Corps of Engineers, Portland District

Open-File Report 2017-1063

U.S. Department of the Interior

U.S. Geological Survey 


\section{U.S. Department of the Interior \\ RYAN K. ZINKE, Secretary}

\section{U.S. Geological Survey \\ William H. Werkheiser, Acting Director}

U.S. Geological Survey, Reston, Virginia: 2017

For more information on the USGS-the Federal source for science about the Earth, its natural and living resources, natural hazards, and the environment-visit https://www.usgs.gov/ or call 1-888-ASK-USGS (1-888-275-8747).

For an overview of USGS information products, including maps, imagery, and publications, visit http:/store.usgs.gov.

Any use of trade, firm, or product names is for descriptive purposes only and does not imply endorsement by the U.S. Government.

Although this information product, for the most part, is in the public domain, it also may contain copyrighted materials as noted in the text. Permission to reproduce copyrighted items must be secured from the copyright owner.

Suggested citation:

Buccola, N.L., 2017, Water temperature effects from simulated changes to dam operations and structures in the Middle and South Santiam Rivers, Oregon: U.S. Geological Survey Open-File Report 2017-1063, 19 p., https://doi.org/10.3133/ofr20171063.

ISSN 2331-1258 (online) 


\section{Contents}

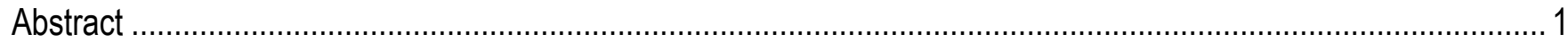

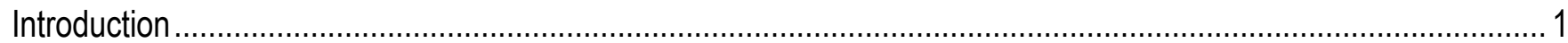

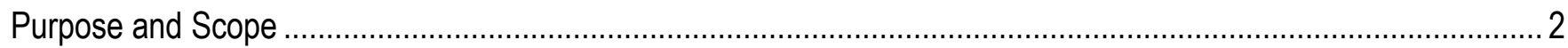

Study Area

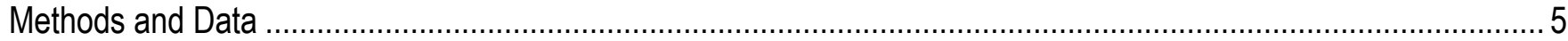

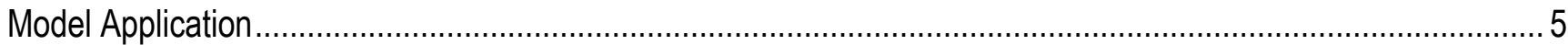

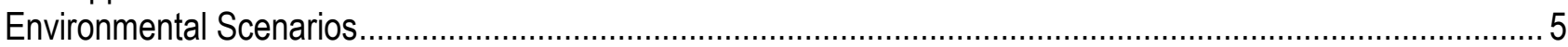

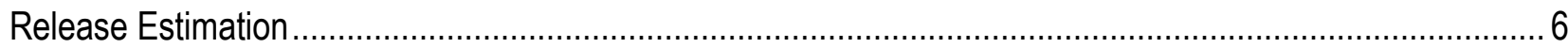

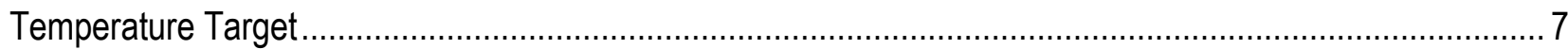

Without-Dam Water Temperature Estimation........................................................................................

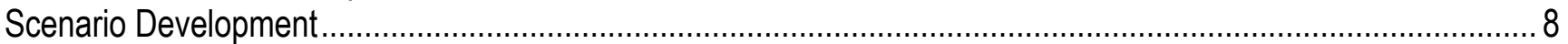

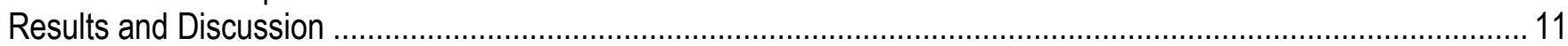

Simulated Oufflows and Lake Levels ................................................................................................. 11

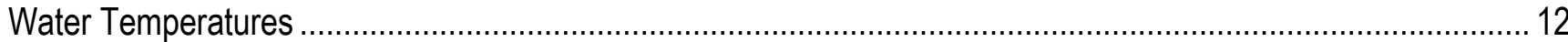

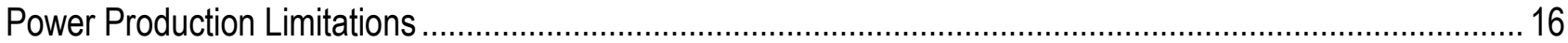

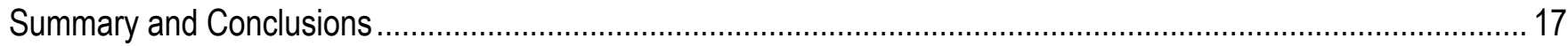

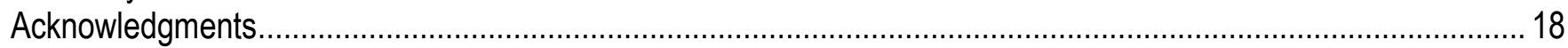

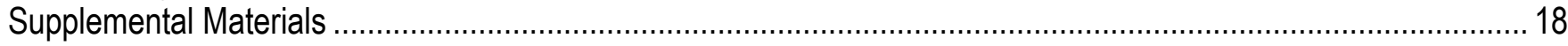

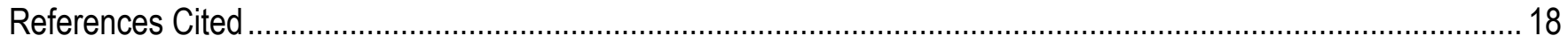

\section{Figures}

Figure 1. Map showing key streamflow-gaging sites, Santiam River Basin study area, Oregon ............................. 3

Figure 2. Graphs showing elevations of operational water levels and structures for Green Peter (GPR) and

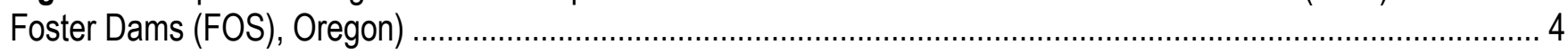

Figure 3. Graph showing total streamflow under wet, normal, and dry environmental scenarios along with historical percentiles for 1936-2011, Foster Lake, Oregon...

Figure 4. Graphs showing 7-day average (A) and 7-day range (B) of release rates over wet, normal, and dry environmental scenarios, Foster Lake (FOS), Oregon.

Figure 5. Graphs showing 7-day average and seven-day range of simulated water levels, Green Peter Lake (GPR; A,B) and Foster Lake (FOS; C, D), Oregon

Figure 6. Graphs showing 7-day average and 7-day range of simulated release water temperature immediately downstream of Green Peter Lake (A, B) and Foster Lake (C,D), Oregon, over wet, normal, and dry environmental scenarios under various operational/structural scenarios

Figure 7. Diagrams showing simulated average $(\mathrm{A})$ and range $(\mathrm{B})$ of release water temperature over wet, normal, and dry calendar-year scenarios in 15-day intervals under operational and structural scenarios, Green Peter Dam, Oregon

Figure 8. Diagrams showing simulated average (A) and range (B) of release water temperature over wet, normal, and dry calendar-year scenarios in 15-day intervals under operational and structural scenarios at Foster Dam, Oregon

Figure 9. Graphs showing 7-day average simulated percent spill under various operational/structural scenarios averaged over wet, normal, and dry calendar-year scenarios, Green Peter Lake (GPR; A) and Foster Lake (FOS; B), Oregon. 


\section{Tables}

Table 1. Minimum flow rules below Foster Lake, Oregon .............................................................................. 7

Table 2. Specification of power constraints, maximum lake levels, refill and drawdown schedules, and outlet schemes for each model scenario, Green Peter Lake (GPR) and Foster Lake, (FOS), Oregon......

Table 3. Details of the use of structural outlets in each model scenario, Green Peter Lake (GPR) and

Foster Lake (FOS), Oregon

\section{Conversion Factors}

Inch/Pound to International System of Units

\begin{tabular}{|c|c|c|}
\hline Multiply & By & To obtain \\
\hline \multicolumn{3}{|c|}{ Length } \\
\hline inch (in.) & 2.54 & centimeter $(\mathrm{cm})$ \\
\hline foot (ft) & 0.3048 & meter $(\mathrm{m})$ \\
\hline mile (mi) & 1.609 & kilometer $(\mathrm{km})$ \\
\hline \multicolumn{3}{|c|}{ Area } \\
\hline acre & 4,047 & square meter $\left(\mathrm{m}^{2}\right)$ \\
\hline square mile $\left(\mathrm{mi}^{2}\right)$ & 2.590 & square kilometer $\left(\mathrm{km}^{2}\right)$ \\
\hline \multicolumn{3}{|c|}{ Volume } \\
\hline acre-foot (acre-ft) & 1,233 & cubic meter $\left(\mathrm{m}^{3}\right)$ \\
\hline \multicolumn{3}{|c|}{ Flow rate } \\
\hline cubic foot per day $\left(\mathrm{ft}^{3} / \mathrm{d}\right)$ & 0.02832 & cubic meter per day $\left(\mathrm{m}^{3} / \mathrm{d}\right)$ \\
\hline square-foot per second $\left(\mathrm{ft}^{2} / \mathrm{s}\right)$ & 0.0929 & square meter per second $\left(\mathrm{m}^{3}\right)$ \\
\hline
\end{tabular}


International System of Units to Inch/Pound

\begin{tabular}{lll}
\hline \multicolumn{1}{c}{ Multiply } & By & \multicolumn{1}{c}{ To obtain } \\
\hline centimeter $(\mathrm{cm})$ & Length & \\
meter $(\mathrm{m})$ & 0.3861 & square mile $\left(\mathrm{mi}^{2}\right)$ \\
kilometer & 3.281 & foot $(\mathrm{ft})$ \\
\hline & 0.6214 & mile $(\mathrm{mi})$ \\
\hline square kilometer $\left(\mathrm{m}^{2}\right)$ & Area & \\
square meter $\left(\mathrm{m}^{2}\right)$ & 0.3861 & square mile $\left(\mathrm{mi}^{2}\right)$ \\
\hline & 0.0002471 & acre \\
\hline meter per second $(\mathrm{m} / \mathrm{s})$ & Volume & \\
cubic meter per second $\left(\mathrm{m}^{3} / \mathrm{s}\right)$ & 3.281 & foot per second $(\mathrm{ft} / \mathrm{s})$ \\
square meter per second $\left(\mathrm{m}^{2} / \mathrm{s}\right)$ & 35.31 & cubic foot per second $\left(\mathrm{ft}^{3} / \mathrm{s}\right)$ \\
millimeter per year per meter $[(\mathrm{mm} / \mathrm{yr}) / \mathrm{m}]$ & 10.764 & square foot per second $\left(\mathrm{ft}^{2} / \mathrm{s}\right)$ \\
\hline
\end{tabular}

Temperature in degrees Celsius $\left({ }^{\circ} \mathrm{C}\right)$ may be converted to degrees Fahrenheit $\left({ }^{\circ} \mathrm{F}\right)$ as ${ }^{\circ} \mathrm{F}=\left(1.8 \times{ }^{\circ} \mathrm{C}\right)+32$.

Temperature in degrees Fahrenheit $\left({ }^{\circ} \mathrm{F}\right)$ may be converted to degrees Celsius $\left({ }^{\circ} \mathrm{C}\right)$ as ${ }^{\circ} \mathrm{C}=\left({ }^{\circ} \mathrm{F}-32\right) / 1.8$.

\section{Datums}

Vertical coordinate information is referenced to the North American Vertical Datum of 1988 (NAVD 88).

Horizontal coordinate information is referenced to the North American Datum of 1983 (NAD 83).

Elevation, as used in this report, refers to distance above the vertical datum.

\section{Abbreviations}

$\begin{array}{ll}\text { CE-QUAL-W2 } & \text { Two-dimensional hydrodynamic and water-quality model } \\ \text { FOS } & \text { Foster Lake } \\ \text { GPR } & \text { Green Peter Lake } \\ \text { RM } & \text { river mile } \\ \text { RO } & \text { Regulating Outlet } \\ \text { RPA } & \text { Reasonable and Prudent Alternative } \\ \text { USACE } & \text { U.S. Army Corps of Engineers } \\ \text { USGS } & \text { U.S. Geological Survey }\end{array}$


This page left intentionally blank 


\title{
Water Temperature Effects from Simulated Changes to Dam Operations and Structures in the Middle and South Santiam Rivers, Oregon
}

\author{
By Norman L. Buccola
}

\begin{abstract}
Green Peter and Foster Dams on the Middle and South Santiam Rivers, Oregon, have altered the annual downstream water temperature profile (cycle). Operation of the dams has resulted in cooler summer releases and warmer autumn releases relative to pre-dam conditions, and that alteration can hinder recovery of various life stages of threatened spring-run Chinook salmon (Oncorhyncus tshawytscha) and winter steelhead (O. mykiss). Lake level management and the use of multiple outlets from varying depths at the dams can enable the maintenance of a temperature regime more closely resembling that in which the fish evolved by releasing warm surface water during summer and cooler, deeper water in the autumn. At Green Peter and Foster Dams, the outlet configuration is such that temperature control is often limited by hydropower production at the dams. Previously calibrated CEQUAL-W2 water temperature models of Green Peter and Foster Lakes were used to simulate the downstream thermal effects from hypothetical structures and modified operations at the dams. Scenarios with no minimum power production requirements allowed some releases through shallower and deeper outlets (summer and autumn) to achieve better temperature control throughout the year and less year-toyear variability in autumn release temperatures. Scenarios including a hypothetical outlet floating 1 meter below the lake surface resulted in greater ability to release warm water during summer compared to existing structures. Later in Autumn (October 15-December 31), a limited amount of temperature control was realized downstream from Foster Dam by scenarios limited to operational changes with existing structures, resulting in 15-day averages within 1.0 degree Celsius of current operations.
\end{abstract}

\section{Introduction}

The existence and operation of 13 dams in the Willamette River Basin, Oregon, owned and operated by the U.S. Army Corps of Engineers (USACE), have altered the natural hydrologic and thermal regime throughout the basin (Gregory and others, 2007). Discharge from many of these dams is unusually warm in autumn, which contributes to high mortality rates of incubating eggs of spring Chinook salmon (Oncorhyncus tshawytscha) (Keefer and others, 2010; Oregon Department of Fish and Wildlife and National Marine Fisheries Service Northwest Region, 2011). Winter steelhead (O. mykiss) and spring Chinook salmon are anadromous fish native to the South Santiam Basin, and both are listed as threatened under the Endangered Species Act (E\&S Environmental Chemistry, Inc., and South Santiam Watershed Council, 2000). Upper Willamette River Chinook salmon in the South Santiam River are considered to be at high risk of extinction (McElhany and others, 2007), and water temperature affected by dam operations is thought to be a limiting factor (National Marine Fisheries Service, 2008). Reasonable and Prudent Alternatives (RPAs) specified in the 2008 Biological Opinion 
from the National Marine Fisheries Service require the evaluation and implementation of feasible operational and (or) structural modifications of the dams to address flow and water-quality effects of USACE projects on Upper Willamette River Chinook salmon and winter steelhead (National Marine Fisheries Service, 2008). The objective of these RPAs is to improve habitat conditions for anadromous fish species listed under the Endangered Species Act that will result in increased egg survival and increased survival of adult and juvenile life stages, causing increases in abundance and productivity.

Water temperatures downstream from dams on the Middle and South Santiam River are not only unnaturally warm from October through December, but also unnaturally cool throughout summer compared with the pre-dam temperatures in which salmonids evolved. Since 2008, similar water temperature conditions below Detroit Dam on the North Santiam River have been modified by blending releases from outlets at different depths (U.S. Army Corps of Engineers, 2012). Green Peter Dam on the Middle Santiam River, upstream from Foster Dam on the South Santiam River, has similar dimensions and outlet types as Detroit Dam, and those outlets could be used to facilitate enhanced water temperature management of the South Santiam River downstream from the dams. Temperature management can be explored by using water temperature models (Buccola and others, 2012) and by "pre-designing" hypothetical temperature-control structures at a dam (Bartholow and others, 2000; Buccola and others, 2016) to help inform management decisions.

CE-QUAL-W2 models of Green Peter and Foster Lakes on the Middle and South Santiam Rivers have been developed to help manage dam releases, understand the effects of the dams on stream temperatures, and plan strategies that will result in water temperatures less detrimental to Chinook salmon and winter steelhead populations (Buccola and others, 2013). CE-QUAL-W2 is a twodimensional, longitudinal-vertical, hydrodynamic and water-quality model constructed and maintained by USACE and Portland State University (Cole and Wells, 2015). The model assumes lateral homogeneity within each cell of the grid, and therefore is well suited for relatively narrow water bodies that tend to stratify, resulting in predominantly longitudinal and vertical water-quality gradients.

\section{Purpose and Scope}

The purpose of this report is to document results of CE-QUAL-W2 simulations of Green Peter Lake (GPR) and the Middle Santiam River from Green Peter Dam downstream to and through Foster Lake (FOS) to the outlets of Foster Dam. Hypothetical operational and structural scenarios were imposed on three separate time-frames (calendar-years) drawn from recent data (since 2002), encompassing a wide range of meteorologic and hydrologic conditions that represented wet, normal, and $d r y$ years. Simulations were designed with the intention of exploring options that could achieve more natural temperatures downstream from Foster Dam, in support of threatened salmon and steelhead recovery in the Willamette Basin.

\section{Study Area}

The Middle and South Santiam Rivers are part of the larger Santiam River Basin and lie in the Western Cascades High Montane ecoregion, with climate characterized by warm dry summers and cool wet winters (fig. 1) (E\&S Environmental Chemistry, Inc., and South Santiam Watershed Council, 2000). The USACE operates Green Peter Dam, which impounds GPR on the Middle Santiam River, and Foster Dam, which impounds FOS downstream from GPR on the South Santiam River. The reservoirs are used for flood-risk management, power generation, irrigation, recreation, and improvement of downstream navigation. 


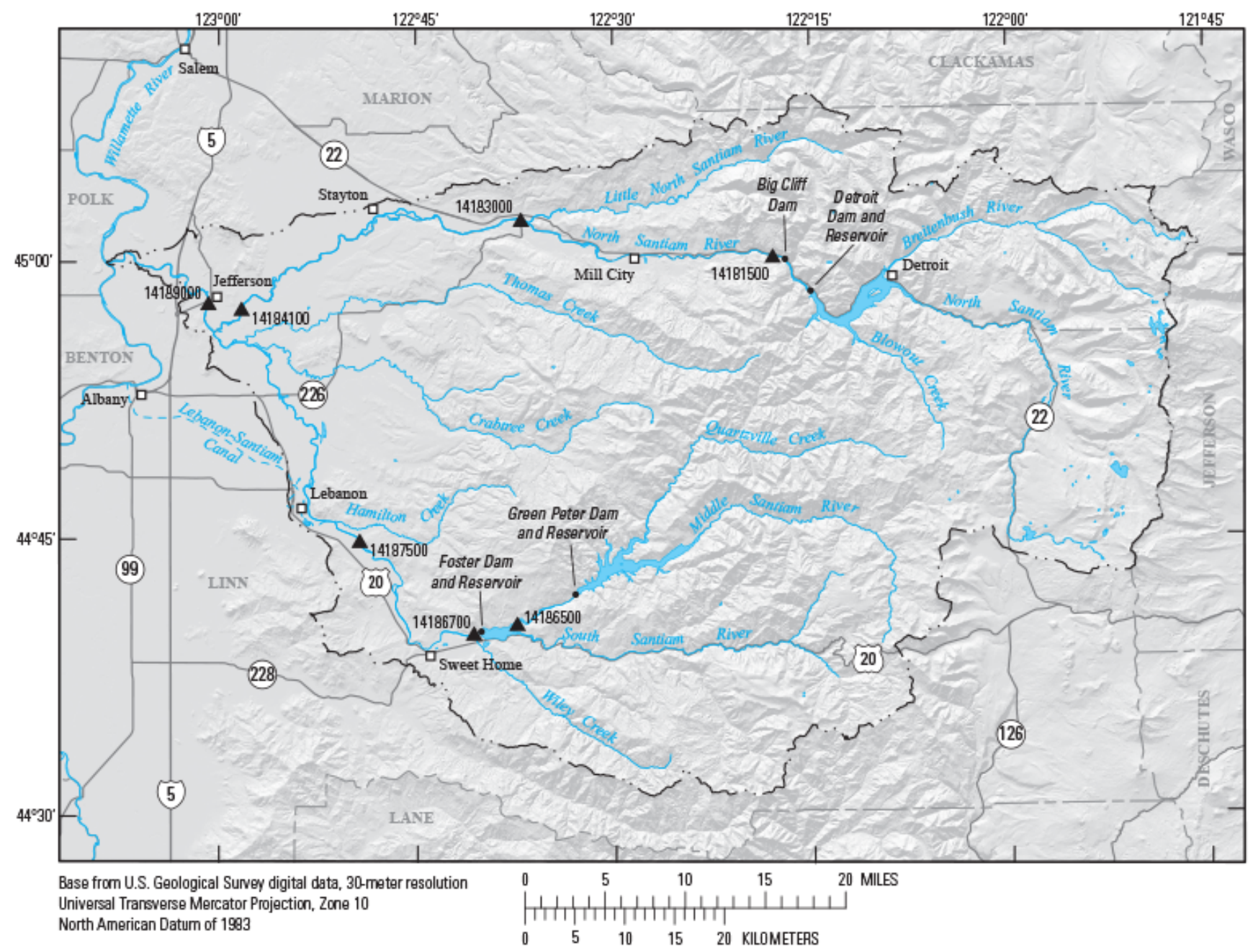

EXPLANATION

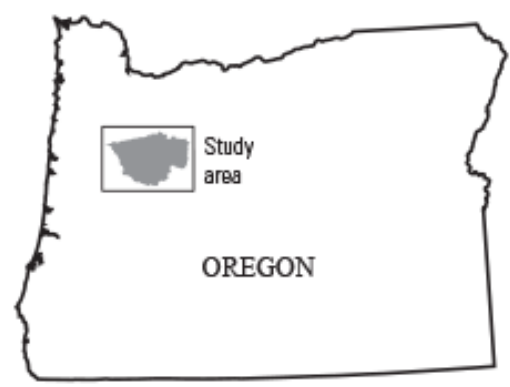

$\Delta \quad$ USGS streamflow gage

Figure 1. Map showing key streamflow-gaging sites, Santiam River Basin study area, Oregon (reproduced from Buccola and others, 2013). 
Green Peter Dam is a 327-ft-high (100-m-high) concrete dam completed in 1968 to form GPR, which is $10 \mathrm{mi}$ long and stores 428,100 acre- $\mathrm{ft}\left(5.28 \times 10^{8} \mathrm{~m}^{3}\right)$ of water at full pool elevation of $1,015 \mathrm{ft}$ (309.4 m). The two largest inflows to GPR are the Middle Santiam River and Quartzville Creek.

Smaller inflows include Whitcomb, Thistle, Tally, and Rumbaugh Creeks. Power generation at Green Peter Dam during peak use hours can lead to large fluctuations in release flows to the Middle Santiam River downstream from the dam.

Foster Dam is a shorter dam (126 ft [38.4 m]) about $8 \mathrm{mi}$ downstream from Green Peter Dam. Foster Dam serves several purposes as a re-regulating dam (operated to smooth the irregular flows released from Green Peter Dam), storage facility, and hydropower generator. Construction of this rockfill dam was completed in 1968. The FOS drainage basin includes $216.3 \mathrm{mi}^{2}$ of evergreen forest and scrub-shrub that is managed largely by the U.S. Forest Service and private entities (Johnson and others, $1985)$. FOS stores 60,700 acre- $\mathrm{ft}\left(7.49 \times 10^{7} \mathrm{~m}^{3}\right)$ of water at a full pool elevation of $641 \mathrm{ft}(195.4 \mathrm{~m})$. Major inflows to FOS include the Middle and South Santiam Rivers.

Green Peter Dam has three fixed-elevation outlets available for releases at different depths in the lake: spillways (two gates at $968.7 \mathrm{ft}[295.3 \mathrm{~m}]$ ), power penstocks (two turbine intakes at $810 \mathrm{ft}$ [246.9 $\mathrm{m}]$ ), and regulating outlets (ROs; two outlets at $750 \mathrm{ft}[228.6 \mathrm{~m}]$ ). Foster Dam has spillways (two gates at $596.8 \mathrm{ft}[181.9 \mathrm{~m}]$ ) and power penstocks (two turbine intakes at $583.3 \mathrm{ft}$ [177.8 m]). These different outlets can be used to release relatively warmer water from near the surface of the lake, and (or) cooler water from deeper in the lake (fig. 2). These outlets have been simplified in the model and are represented as one outlet at each dam for each depth.
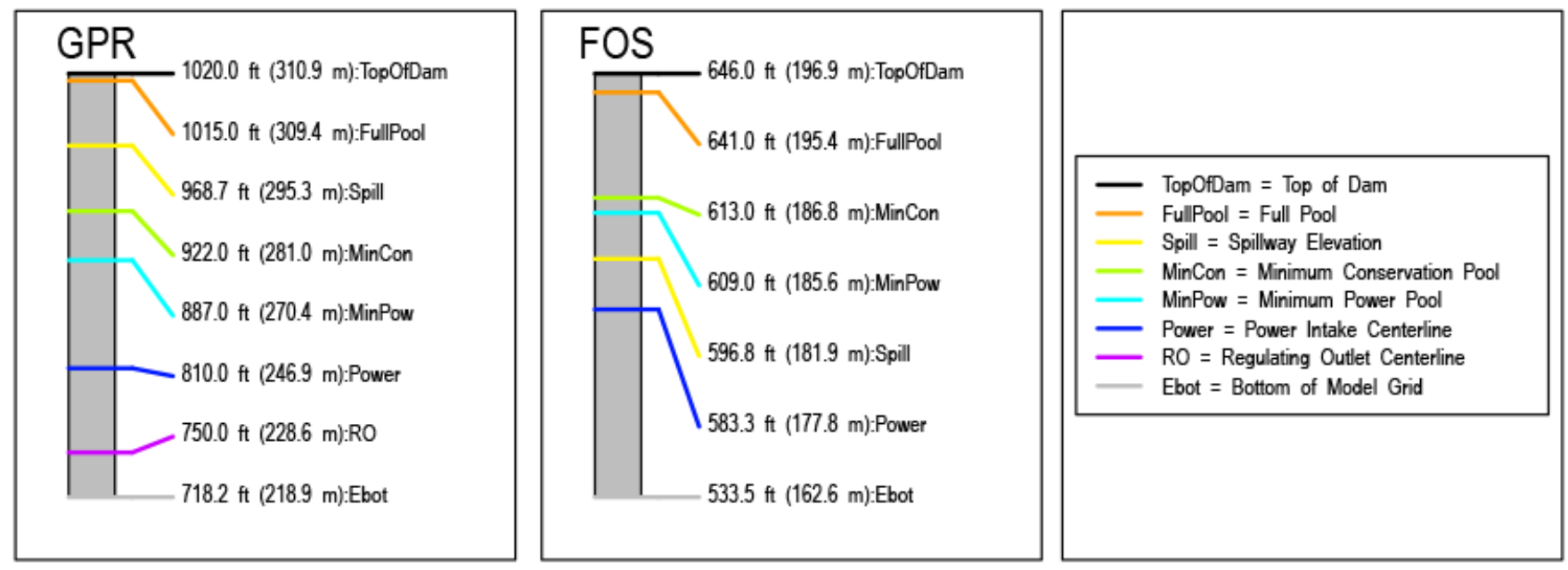

Figure 2. Graphs showing elevations of operational water levels and structures for Green Peter (GPR) and Foster Dams (FOS), Oregon (reproduced from Buccola and others, 2013) 


\section{Methods and Data}

The GPR and FOS CE-QUAL-W2 models were developed previously for 2002, 2006, and 2008 to simulate water-surface elevations, flow, velocities, and water temperatures (Buccola and others, 2013; West Consultants, Inc., 2005). This study updated those models to CE-QUAL-W2 version 3.72 (available at http://www.ce.pdx.edu/w2/) (Cole and Wells, 2015) to allow the easy application of recent temperature blending algorithms upgrades (Rounds and Buccola, 2015). Some model inputs developed in this study, such as a time-series temperature target, were used to allow the model to optimize release temperatures to meet a downstream temperature.

\section{Model Application}

CE-QUAL-W2 requires time series inputs of streamflow, water temperature, and six meteorological parameters: air temperature, dew-point temperature, wind speed, wind direction, cloud cover, and solar radiation. All meteorological, flow, and water temperature boundary conditions for the models were based on those developed for the calendar years 2002, 2006, and 2008and documented in Buccola and others (2013). Simulated release temperatures from those model runs resulted in mean absolute errors less than 0.48 and 0.65 downstream from GPR and FOS, respectively.

\section{Environmental Scenarios}

Three different environmental forcing scenarios, encompassing streamflow inputs, inflow temperatures, and weather conditions, were developed to provide a range of conditions imposed upon the models for evaluating temperature management options in the South Santiam River Basin. To ensure that the streamflow, water temperature, and meteorological datasets used to drive the models were consistent with one another, the simplest approach was to use historical datasets that represented a wide range of possible hydrologic conditions, including wet, normal, and dry conditions. Recent time frames $(2002,2006,2008)$ based on an analysis of the historical streamflow percentiles in the Middle Fork Willamette River basin, near the South Santiam River basin, were used for this study (Buccola and others, 2013; Buccola and others, 2016). These years were chosen not only to encompass a wide range of flow conditions, but also to allow a comparison to recent water temperature measurements that the models could be calibrated to (Buccola and others, 2013). Data from 2006 and 2008 were split on October 19 and concatenated to each other to better represent the normal (2006 data prior to Oct. 19, with 2008 data after Oct. 19) and wet (2008 data prior to Oct. 19, with 2006 data after Oct. 19) scenarios (fig. 3). Relatively dry conditions were represented with data from 2002. 


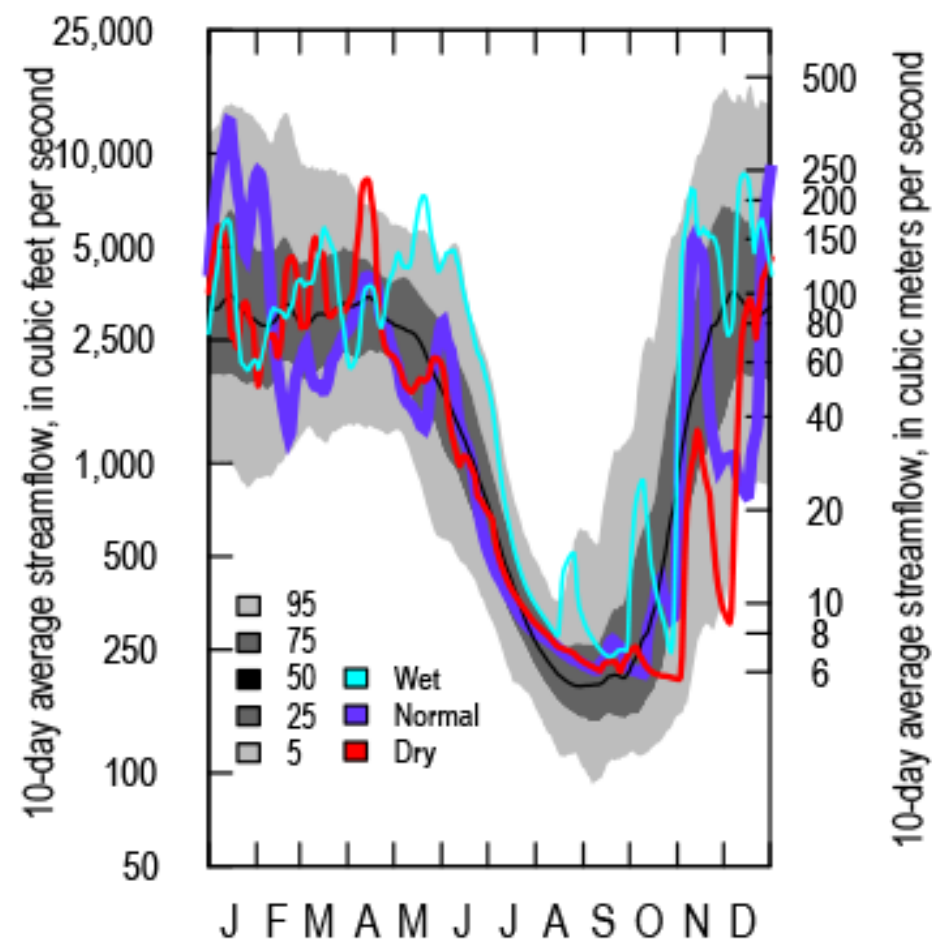

Figure 3. Graph showing total streamflow under wet, normal, and dry environmental scenarios along with historical percentiles for 1936-2011, Foster Lake, Oregon.

\section{Release Estimation}

The total release rates (outflows) from FOS in the model scenarios were set to adhere to the following conditions:

1. Releases from Foster Dam should meet minimum flow requirements ranging from 800 (for rearing habitat) to $1,500 \mathrm{ft}^{3} / \mathrm{s}$ (for Chinook and steelhead spawning) as specified in table 1 , similar to flows specified in the Willamette River BiOp (National Marine Fisheries Service, 2008, table 9.2-2).

2. Simulated water levels in GPR and FOS should not exceed the reservoir rule curve (the operational target for the lake water-surface elevation throughout the year) for more than 5 days when the lake is at full-pool elevation.

3. Release rates from GPR and FOS should not exceed 8,000 and $18,000 \mathrm{ft}^{3} / \mathrm{s}$, respectively, at any time for normal flood control regulation (National Marine Fisheries Service, 2008, table 2-4).

Superimposed on these rules is the fact that GPR is operated on a "power peaking" schedule in which the power penstocks are open to release only during morning and evening. However, the calculated daily average outflow was used in this study to facilitate the optimization and simulation of FOS levels downstream from GPR. A comparison of peaking and non-peaking operations resulted in relatively small release temperature residuals downstream from GPR and FOS (average absolute daily difference between peaking and non-peaking operations of $0.2{ }^{\circ} \mathrm{C}$ immediately below GPR and $0.0^{\circ} \mathrm{C}$ below FOS). 
Table 1. Minimum flow rules below Foster Lake, Oregon.

[Abbreviations: Chinook, spring Chinook salmon (Oncorhynchus tshawytscha); steelhead, winter steelhead (O. mykiss)]

\begin{tabular}{lccccccc}
\hline & $\begin{array}{c}\text { January 1- } \\
\text { January 31 } \\
\text { Chinook } \\
\text { incubation }\end{array}$ & $\begin{array}{c}\text { February 1- } \\
\text { March 15 } \\
\text { rearing }\end{array}$ & $\begin{array}{c}\text { March 16- } \\
\text { May 15 } \\
\text { steelhead } \\
\text { spawning }\end{array}$ & $\begin{array}{c}\text { May 16- } \\
\text { June 30 } \\
\text { steelhead } \\
\text { incubation }\end{array}$ & $\begin{array}{c}\text { July 1- } \\
\text { August 31 } \\
\text { Rearing }\end{array}$ & $\begin{array}{c}\text { September 1- } \\
\text { October 15 } \\
\text { Chinook } \\
\text { spawning }\end{array}$ & $\begin{array}{c}\text { October 16- } \\
\text { December 13 } \\
\text { Chinook } \\
\text { incubation }\end{array}$ \\
\hline Base/FOSMayRefill & 1,100 & 800 & 1,500 & 1,100 & 800 & 1,500 & 1,100 \\
\hline
\end{tabular}

\section{Temperature Target}

The CE-QUAL-W2 v3.72 blending algorithm can optimize the use of multiple release outlets at a dam to meet a time-varying temperature target. Monthly mean temperatures measured 0.7 mi upstream from the mouth of the Middle Santiam River, prior to construction of Green Peter and Foster Dams from 1954 to 1962 (site 14-1865 in Moore, 1964), were used as a temperature target for both the GPR and FOS models. These pre-dam temperatures from the Middle Santiam River follow a natural seasonal pattern, ranging from a low of about $5.0^{\circ} \mathrm{C}\left(41.0^{\circ} \mathrm{F}\right)$ in winter to a high of near $19.0^{\circ} \mathrm{C}\left(66.2^{\circ} \mathrm{F}\right)$ in July.

\section{Without-Dam Water Temperature Estimation}

Without-dam water temperatures for the Middle and South Santiam River under the flow and meteorological conditions of the model scenarios were estimated at Green Peter Dam and Foster Dam to serve as a reference for model scenario results. Contrary to the pre-dam water temperature measurements used for the temperature target, without-dam temperature estimates were computed using a simple mass and energy balance approach combined with a nominal downstream warming rate applied during summer, following methods documented by Rounds (2010).

Without-dam temperatures at the Green Peter Dam site were derived using measured or estimated water temperatures from the Quartzville Creek and Middle Santiam River sites (USGS 14185900 and 14185800, respectively [U.S. Geological Survey, 2016]) upstream from Green Peter Lake for the 2002, 2006, and 2008 time periods described in "Environmental Scenarios." A maximum downstream warming rate of $0.11^{\circ} \mathrm{C} / \mathrm{mi}$ was applied over a distance of 10.2 and $9.4 \mathrm{mi}$ from sites 14185900 and 14185800 to the Green Peter Dam site.

Without-dam temperatures at the Foster Dam site were estimated by warming the Quartzville Creek, Middle Santiam, and South Santiam (USGS 14185000) temperatures for 17.6, 19.2, and $9.0 \mathrm{mi}$ downstream to the Foster Dam site and doing a mass and energy balance of those inputs at the dam site location.

From November 1 to April 13, or any time of year when water temperatures were less than 10 ${ }^{\circ} \mathrm{C}$, no instream warming adjustments were made. From April 14 to October 31, a downstream warming rate was applied as a function of the measured or estimated upstream water temperature, based on an assumption that warmer water was an indication of conditions that were favorable for some warming as water moved from the measurement location to the dam site. The maximum downstream warming rate of $0.11{ }^{\circ} \mathrm{C} / \mathrm{mi}$, for water temperature above $16{ }^{\circ} \mathrm{C}$, was based on historical data (Moore, 1964 and 1967) and previous modeling results (Rounds, 2010). Upstream water temperatures less than $16^{\circ} \mathrm{C}$ but greater than $10^{\circ} \mathrm{C}$ were increased to account for some downstream warming, but at a rate that was less than the maximum rate of $0.11^{\circ} \mathrm{C} / \mathrm{mi}$, using the following linear interpolation: 


$$
\mathrm{T}=\mathrm{T}_{\text {est }}+0.11\left({ }^{\circ} \mathrm{C} / \mathrm{mi}\right) * \text { distance }(\mathrm{mi})\left(\mathrm{T}_{\text {est }}-10.0\right) /(16.0-10.0), 10.0 \leq \mathrm{T}_{\text {est }} \leq 16.0
$$

where

$\mathrm{T}_{\text {est }} \quad$ is upstream measured or estimated water temperature in degrees Celsius, and $\mathrm{T} \quad$ is downstream water temperature estimate in degrees Celsius.

Water temperatures from the Green Peter and Foster Dam sites that incorporated warming were then weighted and averaged based on the streamflow in each tributary as follows:

$$
\mathrm{T}_{\text {mix }}=\left(\mathrm{Q}_{1} \mathrm{~T}_{1}+\mathrm{Q}_{2} \mathrm{~T}_{2}\right) /\left(\mathrm{Q}_{1}+\mathrm{Q}_{2}\right)
$$

where
$\mathrm{T}_{\text {mix }}$
$\mathrm{Q}_{1}, \mathrm{Q}_{2}$
is mixed water temperature estimate in degrees Celsius,
$\mathrm{T}_{1}, \mathrm{~T}_{2}$
is upstream tributary streamflow, and
is upstream tributary water temperature in degrees Celsius.

\section{Scenario Development}

Many scenarios were developed to test the potential downstream effects of altered rule curves, hydropower demands, minimum summer streamflow requirements, and hypothetical structures at Green Peter and Foster Dams. All scenarios were applied with the models using a time-series pre-dam temperature target to determine the extent to which current operations and structures at Green Peter and Foster Dams would be able to meet the temperature target in each of the three environmental scenarios (dry, normal, wet). These results then were compared to reference conditions (existing operations and without-dams estimates) for perspective. The greater depth and storage available at GPR, compared to FOS, allowed greater potential temperature management at GPR. For this reason, the same temperature target was used at both GPR and FOS (see section, "Temperature Target"), even though very little temperature blending was possible at FOS. As scenarios were developed, emphasis was placed on the goal of trying to achieve without-dam water temperatures downstream from FOS; slightly different from the temperature target that was applied to the models. This involved some iteration with regards to the timing of the temperature target, as some heating occurs in the reach between GPR and FOS, yet FOS is relatively limited in ability to blend releases to meet a temperature target. As scenarios were developed, emphasis was placed on the goal of trying to achieve without-dam water temperatures downstream from the dams while evaluating the spectrum of potential temperature management options. Aside from hydropower production constraints, some flexibility to access and release water with a range of temperatures currently exists at Green Peter Dam with its spillway, power, and regulating outlets at a range of depths in the lake. Although both Green Peter and Foster Dams currently have spillway outlets that provide some ability to release warm water from near the surface of each lake, the spillway elevation at either dam is about $45 \mathrm{ft}$ below full pool elevation (fig. 2). While these spillway elevations are not capable of releasing the warmest water near the surface at full pool, they allow for the release of some warm water many days each summer as well as near-surface releases when the lake is filling or drafting (spring or autumn).

Four operational scenarios were formulated through consultation with USACE staff and simulated to evaluate the effectiveness of temperature management through the manipulation of lake level and release rates and the use of various outlets, but without any new release structures. The Base scenario consisted of lake elevations at both dams adhering closely to current minimum release rates and the current rule curve. 
The NoBlend scenario restricted outflows to be released only from the power outlet. The Noppmin scenario prioritized temperature blending operations over power production. Both NoBlend and Noppmin specified total release rates (and lake elevations) identical to Base scenarios operations. Lastly, the FOSMayRefill scenario altered the refill schedule at FOS, beginning on May 15 to resemble USACE operations at FOS since about 1987 to facilitate downstream passage of juvenile winter steelhead and spring-run Chinook salmon April 15 to May 15 (table 2).

Three structural scenarios included the use of existing structures as well as the inclusion of hypothetical floating surface withdrawals at GPR (GPRFloat), FOS (FOSFloat), or both GPR and FOS (GPRFOSFloat) (tables 2 and 3). All structural scenarios specified total release rates from the dams identical to Base operations. Hypothetical floating structures were assumed to be $1 \mathrm{~m}$ below the lake surface year-round. The model parameters defining these structures were based on values developed during the calibration of the models for the existing spillway outlets at the dams. Hypothetical floating versions of the spillway outlets were meant to mimic the size and characteristics of existing spillway gates at Green Peter and Foster Dams.

Table 2. Specification of power constraints, maximum lake levels, refill and drawdown schedules, and outlet schemes for each model scenario, Green Peter Lake (GPR) and Foster Lake, (FOS), Oregon.

[Italicized text denotes operational scenarios; italicized and bold denotes structural scenarios; gray denotes without-dams scenarios]

\begin{tabular}{|c|c|c|c|c|c|c|c|c|}
\hline \multirow[b]{2}{*}{ Scenario name } & \multicolumn{6}{|c|}{ Operations } & \multicolumn{2}{|c|}{ Structures } \\
\hline & \multicolumn{2}{|c|}{$\begin{array}{l}\text { Minimum power } \\
\text { release (percent) }\end{array}$} & \multicolumn{2}{|c|}{$\begin{array}{l}\text { Maximum } \\
\text { lake } \\
\text { elevation }\end{array}$} & \multicolumn{2}{|c|}{ Refill/drawdown time } & \multicolumn{2}{|c|}{ Outlet scheme } \\
\hline NoBlend & 100 & 100 & 1,010 & 637 & Feb./Sept. & Feb./Sept. & Existing & Existing \\
\hline Base & 40 & 40 & 1,010 & 637 & Feb./Sept. & Feb./Sept. & Existing & Existing \\
\hline Noppmin & 0 & 0 & 1,010 & 637 & Feb./Sept. & Feb./Sept. & Existing & Existing \\
\hline GPRFloat & 0 & 40 & 1,010 & 637 & Feb./Sept. & Feb./Sept. & $\begin{array}{c}\text { Floating } \\
\text { outlet }\end{array}$ & Existing \\
\hline FOSFloat & 40 & 0 & 1,010 & 637 & Feb./Sept. & Feb./Sept. & Existing & $\begin{array}{c}\text { Floating } \\
\text { outlet }\end{array}$ \\
\hline
\end{tabular}


Table 3. Details of the use of structural outlets in each model scenario, Green Peter Lake (GPR) and Foster Lake (FOS), Oregon.

[CE-QUAL-W2 model parameters: PRIORITY (model prioritizes lower numbered outlets when in blending mode), MINFRAC (minimum fraction of total outflow to be released from outlet), and DEPTH (floating outlet depth below the water surface) are parameters found in the w2_selective.npt file. Abbreviations: RO, regulating outlet; GPR, Green Peter Lake; FOS, Foster Lake]

\begin{tabular}{|c|c|c|c|c|c|c|c|}
\hline \multirow[b]{2}{*}{ Scenario } & \multirow{2}{*}{$\begin{array}{l}\text { Structure } \\
\text { name }\end{array}$} & \multicolumn{3}{|c|}{ GPR } & \multicolumn{3}{|c|}{ FOS } \\
\hline & & PRIORITY & MINIFRAC & $\begin{array}{l}\text { DEPTH } \\
\text { (meter) }\end{array}$ & PRIORITY & MINIFRAC & $\begin{array}{l}\text { DEPTH } \\
\text { (meter) }\end{array}$ \\
\hline No Blend & Power & \multicolumn{6}{|c|}{ Not applicable } \\
\hline \multirow[t]{3}{*}{ Base/FosMayRefill } & Spillway & 2 & 0.0 & 0.0 & 2 & 0.0 & 0.0 \\
\hline & Power & 1 & 0.4 & 0.0 & 1 & 0.4 & 0.0 \\
\hline & RO & 2 & 0.0 & 0.0 & \multicolumn{3}{|c|}{ Not applicable } \\
\hline \multirow[t]{3}{*}{ Noppmin } & Spillway & 2 & 0.0 & 0.0 & 2 & 0.0 & 0.0 \\
\hline & Power & 1 & 0.0 & 0.0 & 1 & 0.0 & 0.0 \\
\hline & RO & 2 & 0.0 & 0.0 & \multicolumn{3}{|c|}{ Not applicable } \\
\hline \multirow[t]{4}{*}{ GPRFloat } & Floating outlet & 2 & 0.0 & 1.0 & \multicolumn{3}{|c|}{ Not applicable } \\
\hline & spillway & \multicolumn{3}{|c|}{ Not applicable } & 2 & 0.0 & 0.0 \\
\hline & Power & 1 & 0.0 & 0.0 & 1 & 0.0 & 0.0 \\
\hline & RO & 2 & 0.0 & 0.0 & \multicolumn{3}{|c|}{ Not applicable } \\
\hline \multirow[t]{4}{*}{ FOSFloat } & Floating outlet & \multicolumn{3}{|c|}{ Not applicable } & 2 & 0.0 & 1.0 \\
\hline & Spillway & 2 & 0.0 & 0.0 & \multicolumn{3}{|c|}{ Not applicable } \\
\hline & Power & 1 & 0.0 & 0.0 & 1 & 0.0 & 0.0 \\
\hline & RO & 2 & 0.0 & 0.0 & \multicolumn{3}{|c|}{ Not applicable } \\
\hline \multirow[t]{3}{*}{ GPRFOSFloat } & Floating outlet & 2 & 0.0 & 1.0 & 2 & 0.0 & 1.0 \\
\hline & Power & 1 & 0.0 & 0.0 & 1 & 0.0 & 0.0 \\
\hline & RO & 2 & 0.0 & 0.0 & \multicolumn{3}{|c|}{ Not applicable } \\
\hline
\end{tabular}




\section{Results and Discussion}

\section{Simulated Outflows and Lake Levels}

Although the scenarios examined apportioning dam releases between various outlets, the amount and timing of total dam releases were identical (Base scenario) for all scenarios in each environmental condition, except for FOSMayRefill. Variable release rates and lake-surface elevations associated with the FOSMayRefill scenario, as compared to the Base (and all other) scenarios (table 2; fig. 4), were important factors affecting the resulting downstream temperatures. The 7-day average range of simulated lake levels over wet, normal, and dry environmental scenarios at GPR and FOS showed that different water levels in the lakes generally could be achieved through modified release rates, but that some variation in lake level among wet and $d r y$ years had to be expected (figs. 5B, 5D). In most environmental scenarios, Base scenarios resulted in simulated lake levels that closely matched the USACE rule curve during spring and early summer, and fell below the rule curve during late summer when minimum release rates and lake levels in FOS were a higher priority than the maintenance of GPR lake level elevations (fig. 5). Base and FOSMayRefill scenarios generally resulted in similar average release rates and lake levels (fig. 5) throughout the year at GPR The greatest variance in release rates and lake level over the environmental scenarios was in the spring and autumn, when inflows were higher and more variable due to the timing of storms and snowmelt (figs. 4B, 5B, 5D). Base scenarios specified total release rates that satisfied the USACE rule curves and minimum flow requirements in place at GPR and FOS.
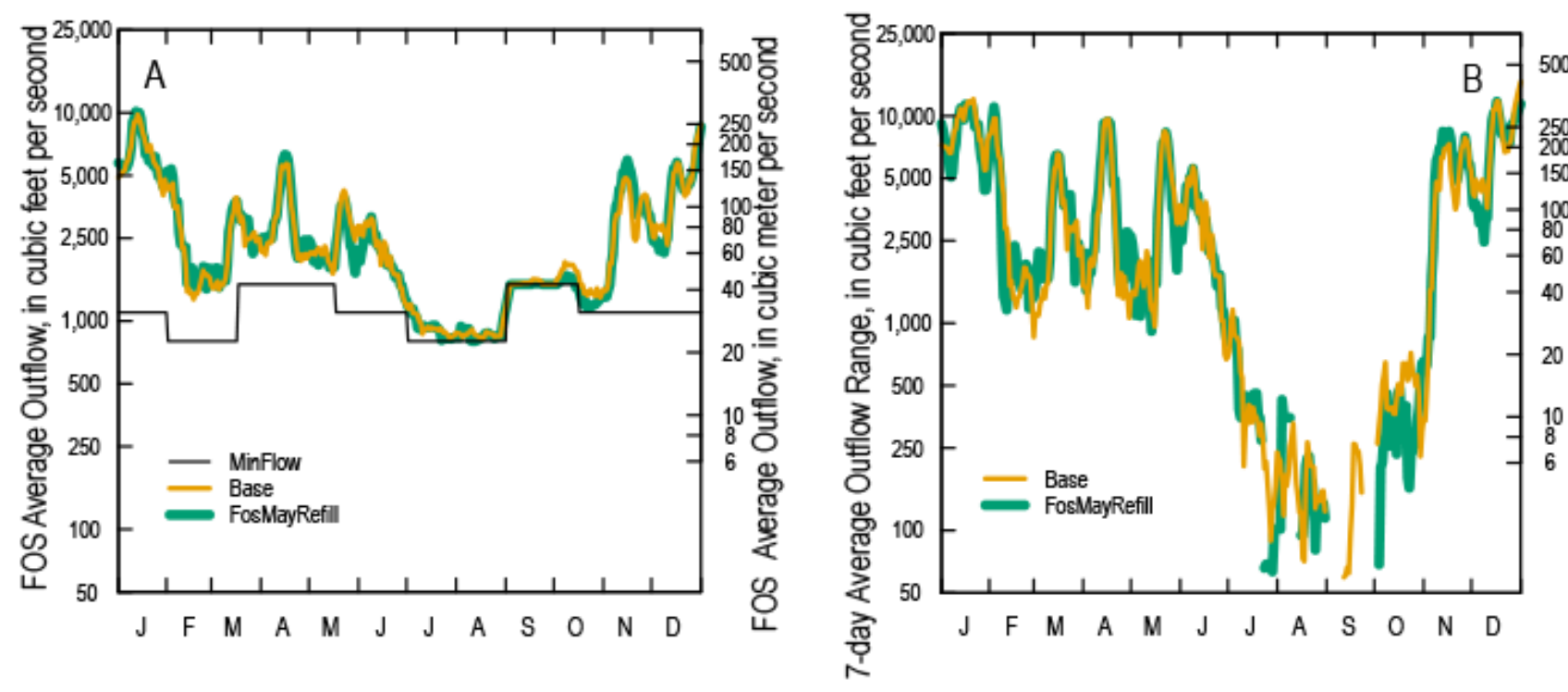

Figure 4. Graphs showing 7-day average (A) and 7-day range (B) of release rates over wet, normal, and dry environmental scenarios, Foster Lake (FOS), Oregon. See table 2 for explanation of scenario names. MinFlow shows the current minimum flow requirement specified by the Biological Opinion. 

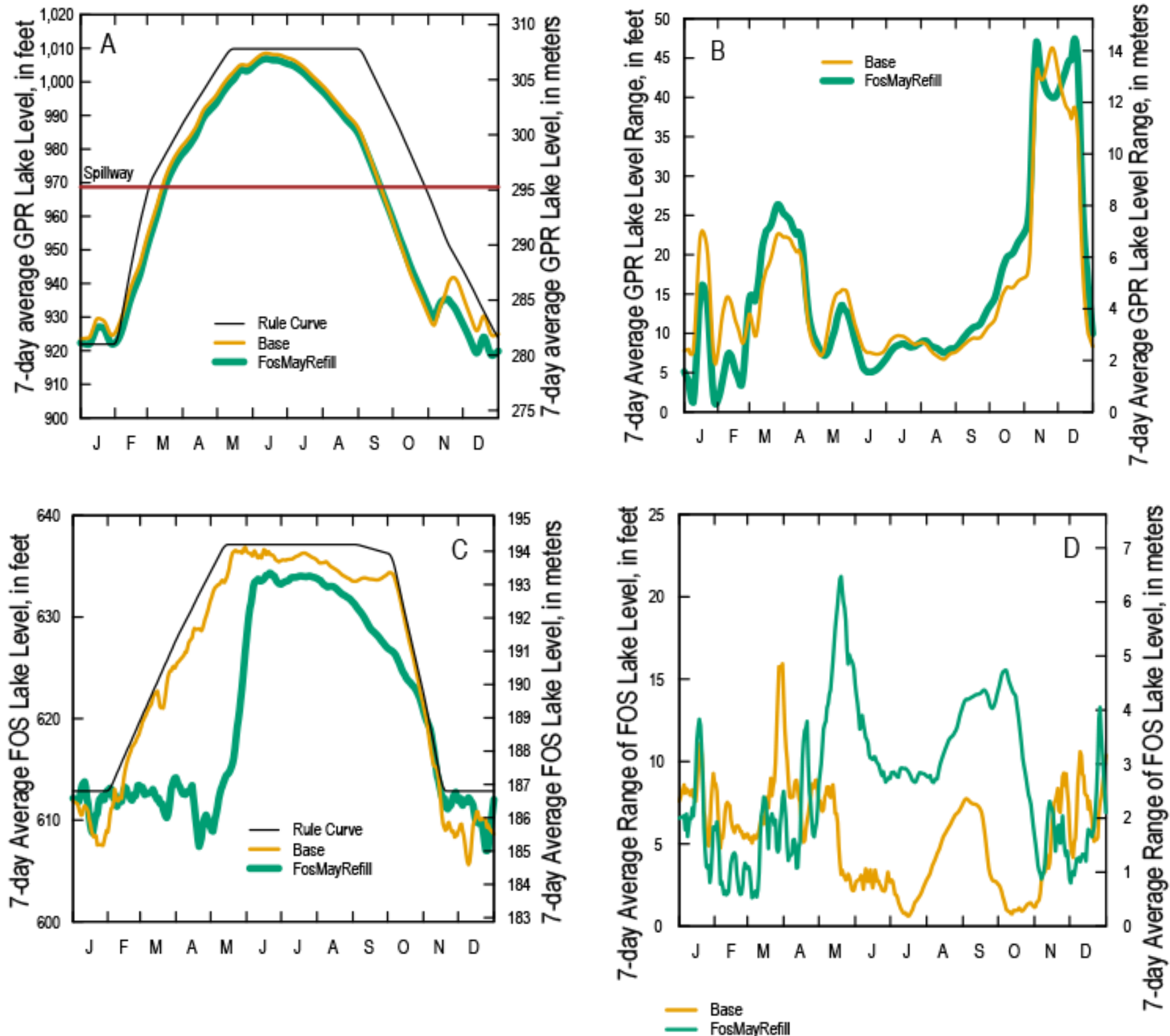

Figure 5. Graphs showing 7-day average and seven-day range of simulated water levels, Green Peter Lake (GPR; $A, B)$ and Foster Lake (FOS; C, D), Oregon.

\section{Water Temperatures}

Results of the operational and structural scenario release temperatures from GPR and FOS were compared in several different ways, including 7-day average and 7-day range plots (fig. 6), and 15-day average and range colored tables (figs. 7-8). Results were calculated over the three environmental scenarios at two locations immediately downstream from GPR and FOS, respectively. GPR and FOS were thermally stratified from spring through autumn with cold water at depth and warmer water near the lake surface in each environmental scenario. Greater control of release temperatures was achieved (while the lakes were stratified) under scenarios that blended releases from both shallow and deep outlets with minimal power production constraints (Noppmin, GPRFloat, GPRFOSFloat) than under scenarios with more power production constraints (NoBlend, Base, FOSMayRefill). The contribution of 
the unregulated South Santiam River between GPR and FOS likely contributed to a more natural seasonal temperature pattern downstream from FOS compared to the site immediately downstream from GPR, using the without-dam estimates as a surrogate for that "natural" seasonal pattern (figs. 6A, 6C). During summer, year-to-year variation in release temperature among environmental scenarios can be linked to the meteorologic conditions and lake elevation, but autumn variations were due more to the presence and release of relatively warm water from GPR in scenarios that did not expel warm water during the summer. The range in results over environmental scenarios was often highest in May-June, and lowest in January-April and September-December (figs. 7B, 8B) over most operational/structural scenarios. The GPRFOSFloat scenarios are omitted from figures $6 \mathrm{~A}-\mathrm{D}$ due to the relatively closeness in results to GPRFloat.
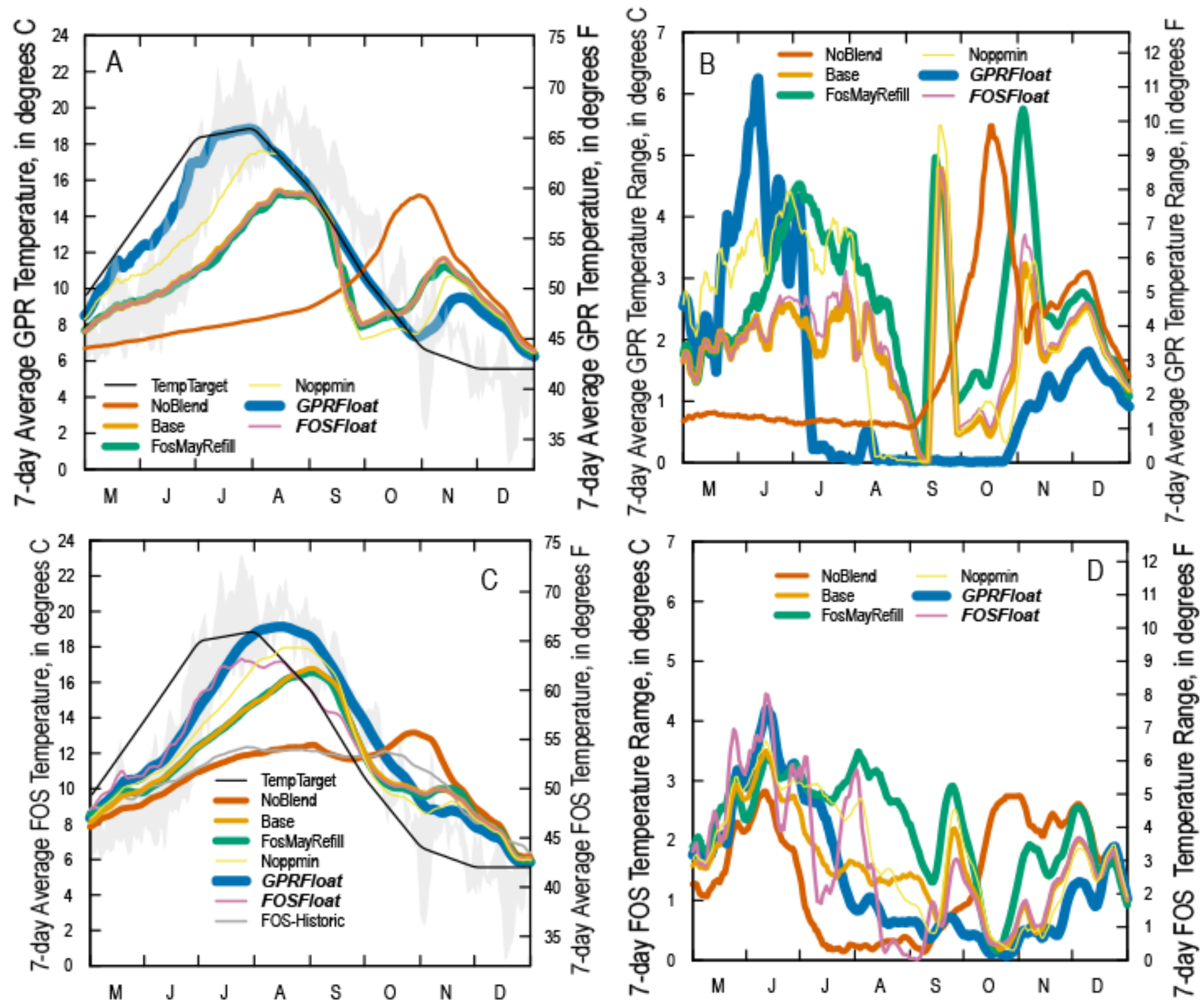

Figure 6. Graphs showing 7-day average and 7-day range of simulated release water temperature immediately downstream of Green Peter Lake (A, B) and Foster Lake (C,D), Oregon, over wet, normal, and dry environmental scenarios under various operational/structural scenarios. Light gray area is the estimated without-dam temperature. Dark gray "FOS-Historic" line represents mean daily temperatures at USGS site 14187200 from 2001 to 2016 . See tables 2 and 3 for an explanation of the named scenarios. 


\begin{tabular}{|c|c|c|c|c|c|c|c|c|c|c|c|c|c|c|c|c|c|c|}
\hline 01-01 & 6.3 & 6.3 & 6.3 & 6.3 & 6.3 & 6.3 & 6.3 & 5.6 & 52 & 01-01 & 0.7 & 0.7 & 0.7 & 0.7 & 0.7 & 0.7 & 0.7 & 2.2 \\
\hline 01-15 & 5.6 & 5.7 & 5.6 & 5.6 & 5.6 & 5.7 & 5.7 & 4.0 & 5.4 & 01-15 & 1.5 & 1.5 & 1.5 & 1.5 & 1.5 & 1.5 & 1.5 & 3.0 \\
\hline $02-01$ & 5.0 & 5.0 & 5.0 & 4.9 & 5.0 & 5.0 & 5.0 & 4.3 & 5.6 & 02-01 & 2.0 & 20 & 2.0 & 1.8 & 2.0 & 1.9 & 1.9 & 1.8 \\
\hline $02-15$ & 5.1 & 5.1 & 5.1 & 5.0 & 5.0 & 5.1 & 5.1 & 4.1 & 5.6 & 02-15 & 1.5 & 1.5 & 1.5 & 1.5 & 1.5 & 1.5 & 1.5 & 1.5 \\
\hline OS-U1 & 5.3 & 5.3 & 5.3 & 5.3 & 5.4 & 5.4 & 5.4 & 4.5 & 6.0 & 03 & 1.4 & 1.3 & 1.3 & 1.4 & 1.3 & 1.1 & 1.1 & 0.8 \\
\hline $\begin{array}{l}03-15 \\
04-01\end{array}$ & 5.6 & 5.7 & 5.7 & 5.7 & 5.7 & 5.8 & 5.8 & 5.0 & 6.8 & 03-15 & 0.6 & 0.9 & 0.9 & 0.9 & 0.9 & 1.0 & 1.0 & 0.6 \\
\hline $04-C$ & 5.9 & 6.5 & 6.5 & 6.4 & 6.7 & 6.8 & 6.8 & 5.9 & 7.9 & 04-01 & 0.4 & 1.0 & 1.0 & 1.0 & 1.2 & 12 & 1.2 & 1.5 \\
\hline 04-1 & 6.5 & 72 & 7.2 & 7.2 & 7.7 & 7.8 & 7.8 & 6.3 & 9.0 & 04-15 & 0.7 & 1.3 & 1.3 & 1.3 & 1.8 & 1.9 & 1.9 & 1.8 \\
\hline $05-0$ & 6.8 & 8.3 & 8.3 & 8.3 & 9.3 & 9.7 & 9.7 & 7.3 & 10.7 & 0 & 0.7 & 1.7 & 1.7 & 1.7 & 2.5 & 22 & 2.2 & 2.1 \\
\hline-1 & 7.1 & 9.1 & 9.1 & 9.2 & 10.6 & 11.7 & 11.7 & 8.7 & 12.9 & $05-15$ & 0.7 & 1.9 & 1.9 & 2.0 & 3.0 & 3.0 & 3.0 & 3.5 \\
\hline 06-01 & 7.3 & 9.6 & 9.6 & 9.6 & 11.3 & 12.9 & 12.9 & 10.1 & 15.1 & $\begin{array}{l}06-01 \\
06-15\end{array}$ & 0.7 & 2.1 & 2.0 & 2.4 & 3.5 & 5.1 & 5.1 & 4.7 \\
\hline $06-15$ & 7.6 & 10.6 & 10.6 & 10.5 & 12.7 & 15.6 & 15.7 & 13.4 & 17.4 & $06-15$ & 0.7 & 23 & 2.4 & 3.7 & 3.8 & 3.6 & 3.5 & 5.6 \\
\hline $00-0$ & 7.9 & 11.8 & 11.7 & 11.5 & 14.3 & 18.0 & 18.0 & 172 & 18.5 & $07-01$ & 0.7 & 20 & 2.4 & 4.3 & 3.4 & 1.6 & 1.5 & 4.2 \\
\hline $01-$ & 8.1 & 13.5 & 13.4 & 13.4 & 16.6 & 18.7 & 18.7 & 19.2 & 18.8 & $07-15$ & 0.6 & 23 & 2.6 & 3.5 & 3.6 & 0.1 & 0.2 & 4.8 \\
\hline $08-01$ & 8.4 & 15.0 & 14.9 & 14.7 & 17.5 & 17.9 & 17.9 & 18.8 & 18.0 & $\begin{array}{l}08-01 \\
08-15\end{array}$ & 0.6 & 20 & 2.0 & 2.9 & 1.4 & 0.2 & 0.4 & 1.4 \\
\hline 08 & 8.8 & 152 & 15.2 & 15.2 & 16.3 & 16.3 & 16.3 & 18.6 & 16.3 & 08- & 0.6 & 1.3 & 1.4 & 1.9 & 0.0 & 0.0 & 0.0 & 1.3 \\
\hline 09-0 & 9.4 & 14.0 & 14.0 & 13.7 & 14.0 & 14.1 & 14.1 & 16.5 & 14.1 & 09-01 & 0.8 & 0.3 & 0.3 & 1.2 & 0.4 & 0.1 & 0.1 & 2.3 \\
\hline 10 & 10.5 & 9.0 & 9.0 & 9.2 & 8.3 & 11.6 & 11.6 & 14.4 & 11.6 & $09-15$ & 1.7 & 23 & 2.1 & 1.7 & 2.7 & 0.1 & 0.1 & 0.9 \\
\hline $10-$ & 12.6 & 8.5 & 8.5 & 8.3 & 7.5 & 9.5 & 9.5 & 11.6 & 9.5 & $10-01$ & 3.9 & 0.6 & 0.7 & 1.4 & 0.8 & 0.0 & 0.0 & 0.5 \\
\hline $10-1$ & 14.8 & 9.2 & 9.2 & 9.2 & 7.7 & 7.7 & 7.7 & 8.6 & 7.5 & $10-15$ & 4.3 & 1.3 & 1.5 & 3.3 & 0.8 & 0.1 & 0.2 & 1.3 \\
\hline 11-01 & 13.7 & 11.3 & 11.3 & 10.9 & 9.5 & 8.3 & 8.3 & 7.7 & 6.4 & 11-01 & 2.2 & 2.5 & 2.8 & 4.0 & 2.6 & 0.7 & 0.7 & 2.7 \\
\hline $11-1$ & 11.1 & 10.4 & 10.4 & 10.3 & 10.1 & 9.3 & 9.3 & 6.5 & 5.8 & $11-15$ & 2.7 & 20 & 2.2 & 2.4 & 1.9 & 1.1 & 1.1 & 0.7 \\
\hline $12-01$ & 9.4 & 8.9 & 8.9 & 8.8 & 8.7 & 8.2 & 8.3 & 5.5 & 5.6 & $12-01$ & 2.9 & 24 & 2.4 & 2.6 & 2.3 & 1.7 & 1.7 & 0.3 \\
\hline $12-15$ & 7.4 & 72 & 7.2 & 7.1 & 7.1 & 6.8 & 6.9 & 4.4 & 5.6 & $\begin{array}{l}12-15 \\
12-31\end{array}$ & 1.8 & 1.5 & 1.6 & 1.6 & 1.4 & 12 & 1.2 & 3.0 \\
\hline
\end{tabular}

Figure 7. Diagrams showing simulated average (A) and range (B) of release water temperature over wet, normal, and dry calendar-year scenarios in 15-day intervals under operational and structural scenarios, Green Peter Dam, Oregon. Scenarios are ordered by average December temperature from left to right. "Temp Target" indicates the model temperature target. See tables 2 and 3 for an explanation of the named scenarios.

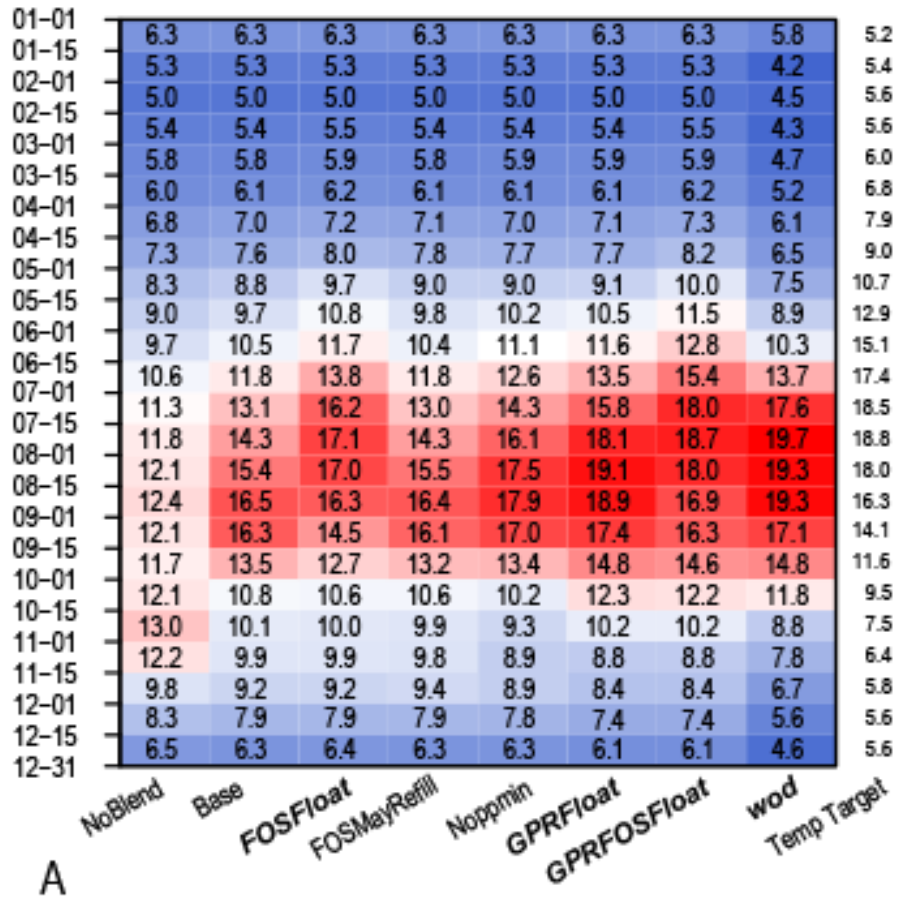

\begin{tabular}{|c|c|c|c|c|c|c|c|c|}
\hline 01-01 & 1.2 & 1.2 & 1.2 & 1.1 & 1.2 & 1.2 & 12 & 2.2 \\
\hline $01-15$ & 2.0 & 2.0 & 2.0 & 1.9 & 2.0 & 2.0 & 20 & 2.9 \\
\hline $02-01$ & 2.2 & 2.1 & 2.1 & 2.1 & 2.1 & 2.1 & 21 & 1.8 \\
\hline $0<-15$ & 0.8 & 0.7 & 0.6 & 0.7 & 0.7 & 0.7 & 0.6 & 1.5 \\
\hline $03-01$ & 0.4 & 0.4 & 0.3 & 0.3 & 0.3 & 0.3 & 0.3 & 0.8 \\
\hline $03-15$ & 0.4 & 0.3 & 0.5 & 0.4 & 0.3 & 0.3 & 0.5 & 0.6 \\
\hline $04-015$ & 1.0 & 1.1 & 1.0 & 1.1 & 1.3 & 1.3 & 1.1 & 1.4 \\
\hline $05-01$ & 1.0 & 1.2 & 1.5 & 1.3 & 1.2 & 1.3 & 1.5 & 1.8 \\
\hline $05-15$ & 1.2 & 1.7 & 2.0 & 2.1 & 1.9 & 1.8 & 1.9 & 2.1 \\
\hline & 2.0 & 2.5 & 2.9 & 26 & 2.8 & 2.7 & 28 & 3.6 \\
\hline $00-1$ & 2.7 & 3.2 & 3.9 & 3.1 & 3.4 & 3.8 & 4.8 & 4.8 \\
\hline $07-10$ & 1.8 & 2.7 & 2.6 & 3.1 & 3.0 & 3.2 & 3.0 & 5.8 \\
\hline & 0.5 & 1.9 & 1.1 & 27 & 2.8 & 2.6 & 1.4 & 4.3 \\
\hline $08-01$ & 0.1 & 1.5 & 2.2 & 29 & 2.5 & 1.4 & 0.1 & 4.8 \\
\hline & 0.2 & 1.4 & 1.3 & 32 & 2.0 & 0.9 & 0.0 & 1.4 \\
\hline $00-01$ & 0.3 & 1.4 & 0.1 & 2.5 & 1.2 & 0.6 & 0.8 & 1.4 \\
\hline & 0.2 & 1.1 & 0.4 & 1.5 & 0.6 & 0.4 & 0.6 & 2.4 \\
\hline $10-01$ & 0.6 & 1.5 & 1.1 & 24 & 1.8 & 0.6 & 0.5 & 1.1 \\
\hline & 1.5 & 0.9 & 0.8 & 1.1 & 1.1 & 0.3 & 0.2 & 0.6 \\
\hline $11-01$ & 2.7 & 0.2 & 0.3 & 0.5 & 0.2 & 0.1 & 0.1 & 1.3 \\
\hline & 2.3 & 0.4 & 0.6 & 1.6 & 0.2 & 0.1 & 0.1 & 2.6 \\
\hline & 2.3 & 1.3 & 1.4 & 1.8 & 1.0 & 0.6 & 0.7 & 0.7 \\
\hline & 2.2 & 1.7 & 1.7 & 2.1 & 1.6 & 1.0 & 1.1 & 0.5 \\
\hline & 1.5 & 1.6 & 1.5 & 1.4 & 1.6 & 1.5 & 1.5 & 3.0 \\
\hline
\end{tabular}

Figure 8. Diagrams showing simulated average (A) and range (B) of release water temperature over wet, normal, and dry calendar-year scenarios in 15-day intervals under operational and structural scenarios at Foster Dam, Oregon. Scenarios are ordered by average December temperature from left to right. "Temp Target" indicates the model temperature target. See tables 2 and 3 for an explanation of the named scenarios. 
NoBlend scenarios made no attempt to meet the temperature target and routed all outflow through the powerhouse outlet. This scenario is similar to current operations at the dams aside from FOS spillway operations during spring for downstream fish passage. NoBlend scenarios resulted in temperatures cooler in summer $\left(-7.9^{\circ} \mathrm{C}\left[14.2^{\circ} \mathrm{F}\right]\right)$ and warmer in autumn $\left(+4.2^{\circ} \mathrm{C}\left[7.6^{\circ} \mathrm{F}\right]\right)$ compared to without-dams temperatures (fig. 8A). NoBlend scenario releases from GPR warmed greatly in midsummer during its transit to and through FOS by as much as $3.7^{\circ} \mathrm{C}\left[6.7^{\circ} \mathrm{F}\right]$ (comparing August averages in figs. 7A and $8 \mathrm{~A})$ and cooled in autumn as much as $1.8^{\circ} \mathrm{C}\left(3.2^{\circ} \mathrm{F}\right)$ (November in figs. 7A, $8 \mathrm{~A}$ ) when averaged over environmental scenarios. Downstream from FOS, NoBlend scenarios resulted in the highest year-to-year temperature variation during the autumn compared to all other structural and operational scenarios (fig. 8B).

Base, FOSMayRefill, and Noppmin scenarios reflect the existing operations and usable outlet structures at Green Peter Dam (spillways, power penstocks, and ROs) and Foster Dam (spillways and power penstocks). The Base and FOSMayRefill scenarios imposed a priority on power generation that limited "spill" (releases through the spillway or RO at GPR and through the spillway at Foster Dam) to a maximum of 60 percent of the total outflow. Typically, the need to meet the operational temperature target resulted in spillway releases during summer at GPR and FOS (accessing warmer surface water to meet a warm temperature target) and RO releases during autumn at GPR (accessing cooler, deeper water to meet a cooler temperature target). The remaining 40 percent of flow was released through the powerhouse outlet (see MINFRAC values in table 3).

Base and FOSMayRefill scenarios allowed for the relaxation of minimum power production constraints (to a minimum of 40 percent) so that some percentage of releases for temperature blending while maintaining current operational rules related to lake level (rule curves) and minimum flow targets. Base and FOSMayRefill scenarios resulted in similar release temperatures at GPR and FOS when averaged over environmental scenarios; generally cooler mid-June through mid-October and warmer mid-October to June compared to without-dam estimates (figs. 7A, 8A). FOSMayRefill resulted in a greater variability (range) among environmental scenarios than Base scenarios, likely due to the higher variability in FOS lake level among different environmental scenarios. Release temperatures under Base and FOSMayRefill scenarios were nearly identical downstream from FOS $\left(<0.2{ }^{\circ} \mathrm{C}\right.$ as a 15 -day difference; fig. 8A).

Noppmin scenarios prioritized temperature blending among existing outlets without minimum power production rules and resulted in temperatures more similar to those produced by structural scenarios. Compared with NoBlend, Noppmin scenarios simulated release temperatures that were $5.5^{\circ} \mathrm{C}$ $\left[9.9^{\circ} \mathrm{F}\right]$ warmer during late August and $3.7^{\circ} \mathrm{C}\left[6.7^{\circ} \mathrm{F}\right]$ cooler during late October downstream from FOS (fig. 8A).

Hypothetical outlets floating $1 \mathrm{~m}$ below the lake surface were included in the GPRFloat, FOSFloat, and GPRFOSFloat scenarios. These scenarios included changes to the structural outlets at the dams, and therefore were assumed to not have any power production constraints because releases after construction might be routed from new and existing structures to the power production facilities. Downstream from FOS, FOSFloat scenarios closely matched Base and FOSMayRefill scenarios, aside from some warmer releases June-August and cooler releases in September (figs. 6C, 8A). While scenarios including floating outlets at GPR (GPRFloat and GPRFOSFloat) came closest to the temperature target year-round, both scenarios achieved similar results despite the inclusion of a floating outlet at FOS in GPRFOSFloat. This illustrates how the potential temperature control at GPR exceeds the potential at FOS when all power production constraints are removed. Structural scenarios and Noppmin (no minimum power constraint) scenarios resulted in the least amount of year-to-year variability (figs. 6B, 6D, 7B, 8B). Downstream from FOS, average release temperatures under Noppmin, GPRFloat, and GPRFOSFloat during Nov 1-Dec 31 were closely matched (within $0.7^{\circ} \mathrm{C}\left[1.3^{\circ} \mathrm{F}\right]$ ). 
There were relatively small differences $\left(<1.4^{\circ} \mathrm{C}\left[2.5^{\circ} \mathrm{F}\right]\right)$ between $B$ ase scenarios and structural scenarios (GPRFloat, FOSFloat, and GPRFOSFloat) outside of May-Oct (fig. 8A) downstream from FOS.

\section{Power Production Limitations}

Power production is an important feature of the dams and is captured in the context of this report in a computation of "percent spill," which is defined as the percentage of the total flow release directed to outlets other than the power penstocks. Thus, spill includes the total releases from the spillway, RO, or any other additional hypothetical structure at GPR or FOS (fig. 9). In reality, some spill can occur during intense rain events, while the lakes are above the rule curve, but these occurrences are typically during times when the lakes are not stratified, so are not highlighted in this study. Under operational scenarios, temperature management with the existing outlet structures at GPR typically consisted of spillway releases during April-September in attempts to meet the relatively warm temperature target, and deeper, cooler RO releases during October-December in attempts to match the cooling temperature target (fig. 9A). Temperature operations at FOS were limited to the spillway usage, primarily during February-May as well as some usage during the summer (fig. 9B).
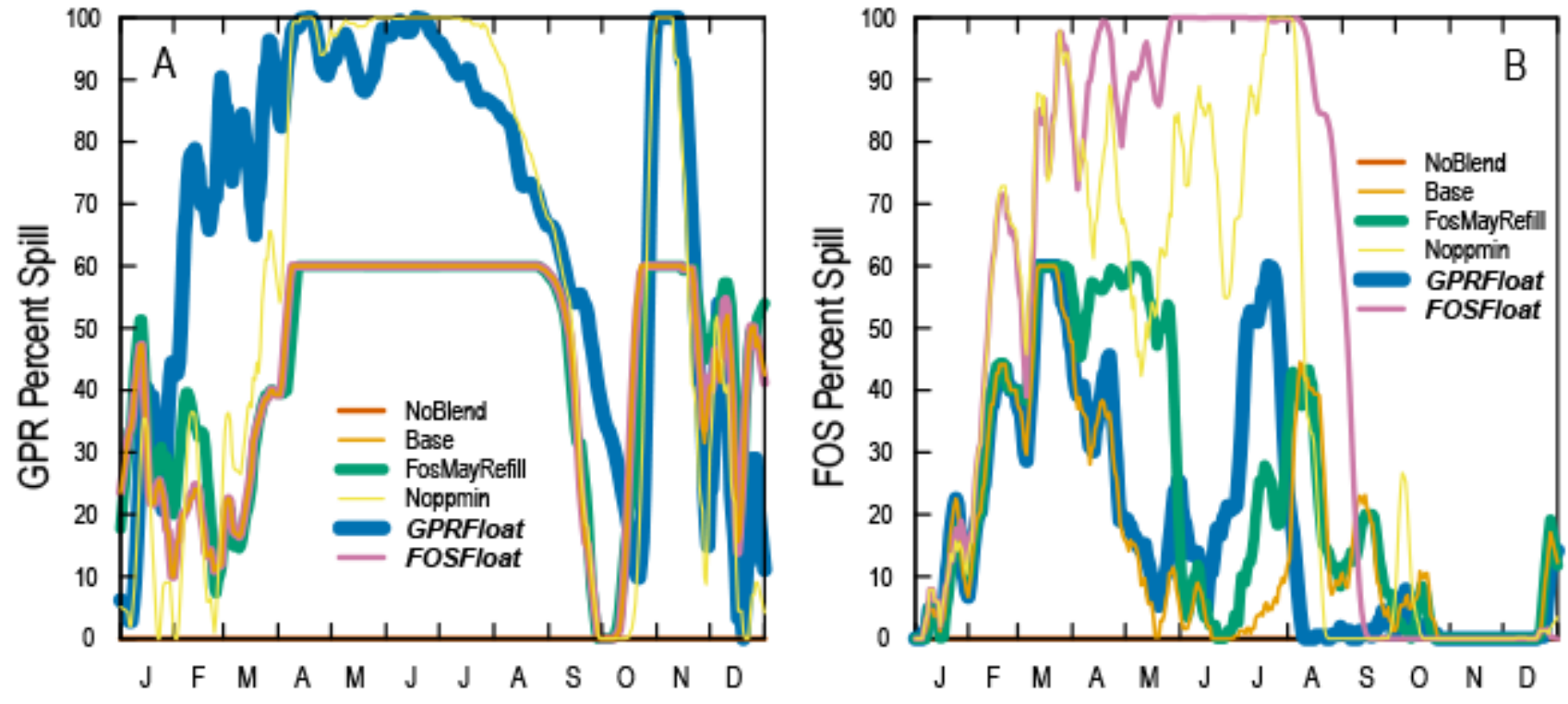

Figure 9. Graphs showing 7-day average simulated percent spill under various operational/structural scenarios averaged over wet, normal, and dry calendar-year scenarios, Green Peter Lake (GPR; A) and Foster Lake (FOS; B), Oregon. See tables 2 and 3 for an explanation of the named scenarios. 


\section{Summary and Conclusions}

The effects of Green Peter and Foster Dams on water temperature in the Middle and South Santiam Rivers are dependent on lake level management, release rates, and the use of multiple outlets from varying depths at the dams. Achievement of a more natural seasonal temperature pattern in these rivers depends on a delicate balance of releases from different dam outlets and the potential sacrifice of some power generation at these dams. Specifically, the ability to release warm surface water during summer and cooler, deeper water in autumn determined the amount of temperature control achieved in each model scenario. While year-to-year variability in meteorological and hydrologic conditions are not controllable, some temperature management of downstream water temperatures in the summer and autumn is possible with the current configuration of outlets at the dams. However, this temperature control is limited by hydropower production at the dams. This study provides a side-by-side comparison of the downstream water temperature effects from potential operational and structural scenarios at Green Peter and Foster Dams to help inform resource management planning related to minimizing thermal effects to the various life stages of salmonids.

Simulations where power production was prioritized over temperature management (NoBlend scenario) led to water temperatures downstream from the dams that were cooler in summer and warmer in autumn compared to without-dams temperatures (difference ranging from $-7.9^{\circ} \mathrm{C}\left[14.2^{\circ} \mathrm{F}\right]$ in late July to $+4.2^{\circ} \mathrm{C}\left[7.6^{\circ} \mathrm{F}\right]$ in late October). By relaxing constraints on minimum power production rules and allowing some percentage of releases through shallower and deeper outlets (summer and autumn, respectively), better temperature control was achieved throughout the year in terms of an enhanced ability to meet a downstream temperature target and a reduction in year-to-year variability in release temperatures.

With the existing outlet configurations at Green Peter and Foster Dams, operational scenarios prioritizing temperature blending among outlets (Noppmin) resulted in a peak potential increase of 5.5 ${ }^{\circ} \mathrm{C}\left[9.9^{\circ} \mathrm{F}\right]$ during late August and a potential decrease of $3.7^{\circ} \mathrm{C}\left[6.7^{\circ} \mathrm{F}\right]$ downstream from the dams during the late October salmon spawning season compared with scenarios prioritizing power-production (NoBlend). Variants on these temperature blending operations led to similar, but smaller maximum differences from NoBlend scenarios in summer and autumn. Temperature control in operational and structural scenarios was generally better during summer and early autumn (mid-June to mid-November) than in other months.

Idealized hypothetical floating release structures at the dams were simulated to quantify the potential for temperature management, assuming that all releases (near the lake surface and at depth) could be routed to the power penstocks. The effect of such a floating structure was greatest immediately downstream from the dam in which it was simulated. For example, a floating outlet scenario at Green Peter Dam resulted in release temperatures that closely matched the temperature target for most of the year, but this same scenario deviated from the target downstream from Foster Dam due to heat exchange in FOS and the influence of the inflowing South Santiam River. Downstream from FOS, temperature control from this type of floating structure was greater during summer than in autumn. Specifically, operational scenarios that exchanged some percentage of power production with releases from other outlets (spillway, RO) for temperature blending achieved about the same ability to meet the temperature target as structural scenarios during October 15-December 31. 


\section{Acknowledgments}

The authors would like to thank Kathy Breen, a former U.S. Geological Survey employee, for assistance in model optimization.

\section{Supplemental Materials}

The models developed and refined during this study, along with the model source code and all model inputs, are available for download on a USGS website at https://or.water.usgs.gov/proj/mfw_ssr_temp/.

\section{References Cited}

Bartholow, J.M., Hanna, B., Saito, L., Lieberman, D., and Horn, M., 2000, Simulated limnological effects of the Shasta Lake temperature control device: Environmental Management, v. 27, no. 4, p. 105-125.

Buccola, N.L, Rounds, S.A., Sullivan, A.B., and Risley, J.C., 2012, Simulating potential structural and operational changes for Detroit Dam on the North Santiam River, Oregon, for downstream temperature management: U.S. Geological Survey Scientific Investigations Report 2012-5231, 68 p. [Also available at https://pubs.usgs.gov/sir/2012/5231/.]

Buccola, N.L., Stonewall, A.J., Sullivan, A.B., Kim, Yoonhee, and Rounds, S.A., 2013, Development of CE-QUAL-W2 models for the Middle Fork Willamette and South Santiam Rivers, Oregon: U.S. Geological Survey Open-File Report 2013-1196, 55 p. [Also available at https://dx.doi.org/10.3133/ofr20131186.]

Buccola, N.L., Turner, D.F., and Rounds, S.A., 2016, Water temperature effects from simulated dam operations and structures in the Middle Fork Willamette River, western Oregon: U.S. Geological Survey Open-File Report 2016-1159, 39 p. [Also available at https://dx.doi.org/10.3133/ofr20161159.]

Cole, T.M., and Wells, S.A., 2015, CE-QUAL-W2-A two-dimensional, laterally averaged, hydrodynamic and water-quality model, version 3.72: Portland, Oregon, Portland State University, Department of Civil and Environmental Engineering, [variously paged].

E\&S Environmental Chemistry, Inc., and South Santiam Watershed Council, 2000, South Santiam watershed assessment: E\&S Environmental Chemistry, Inc., and South Santiam Watershed Council, Final report, $224 \mathrm{p}$.

Gregory, S., Ashkenas, L., and Nygaard, C., 2007, Summary report to assist development of ecosystem flow recommendations for the Middle Fork and Coast Fork of the Willamette River, Oregon: Corvallis, Oregon State University, Institute for Water and Watersheds, $237 \mathrm{p}$.

Johnson, D., Petersen, R., Lycan, D., Sweet, J., Newhaus, M., and Schaedel, A., 1985, Atlas of Oregon lakes: Corvallis, Oregon State University Press, 319 p., updated atlas information accessed July 23, 2013, at http://aol.research.pdx.edu.

Keefer, M.L., Taylor, G.A., Garletts, D.F., Gauthier, G.A., Pierce, T.M., and Caudill, C.C., 2010, Prespawn mortality in adult spring Chinook salmon outplanted above barrier dams: Ecology of Freshwater Fish, v. 19, p. 361-372. [Also available at http://dx.doi.org/10.1111/j.16000633.2010.00418.x.]

McElhany, P., Chilcote, M., Myers, J., and Beamesderfer, R., 2007, Viability status of Oregon salmon and steelhead populations in the Willamette and lower Columbia Basins:, Seattle, Washington, Prepared for Oregon Department of Fish and Wildlife and National Marine Fisheries Service, Northwest Fisheries Science Center. 
Moore, A.M., 1964, Compilation of water-temperature data for Oregon streams: U.S. Geological Survey Open-File Report 64-115, 134 p. +1 pl. [Also available at https://pubs.er.usgs.gov/publication/ofr64115.]

Moore, A.M., 1967, Correlation and analysis of water-temperature data for Oregon streams: U.S. Geological Survey Water-Supply Paper 1819-K, 53 p. +1 pl. [Also available at https://pubs.er.usgs.gov/publication/wsp1819K.]

National Marine Fisheries Service, 2008, Willamette Basin Biological Opinion-Endangered Species Act Section 7(a)(2) Consultation: National Oceanic and Atmospheric Administration Fisheries Log Number F/NWR/2000/02117 [variously paged].

Oregon Department of Fish and Wildlife and the National Marine Fisheries Service Northwest Region, 2011, Upper Willamette River conservation and recovery plan for Chinook salmon and steelhead, FINAL-August 5, 2011: Oregon Department of Fish and Wildlife and the National Marine Fisheries Service Northwest Region, 462 p., accessed, July 23, 2013, at http://www.nmfs.noaa.gov/pr/pdfs/recovery/chinook_steelhead_upperwillametteriver.pdf.

Rounds, S.A., 2010, Thermal effects of dams in the Willamette River Basin, Oregon: U.S. Geological Survey Scientific Investigations Report 2010-5153, 64 p. [Also available at https://pubs.usgs.gov/sir/2010/5153/.]

Rounds, S.A., and Buccola, N.L., 2015, Improved algorithms in the CE-QUAL-W2 water-quality model for blending dam releases to meet downstream water-temperature targets: U.S. Geological Survey Open-File Report 2015-1027, 36 p. [Also available at https://dx.doi.org/10.3133/ofr20151027.]

U.S. Army Corps of Engineers, 2012, Willamette Basin annual water quality report for 2011: Final Report, April 2012, 123 p.

U.S. Geological Survey, 2016, National Water Information System-Web interface: Website, accessed May 4, 2016, at https://waterdata.usgs.gov/or/nwis/sw.

West Consultants, Inc., 2005, Development of a CE-QUAL-W2 model for Green Peter and Foster reservoirs: Seattle, Washington, prepared for U.S. Army Corps of Engineers under contract DACW57-02-D-0005, 43 p. 

Publishing support provided by the U.S. Geological Survey Science Publishing Network, Tacoma Publishing Service Center

For more information concerning the research in this report, contact the Director, Oregon Water Science Center

U.S. Geological Survey

2130 SW 5th Avenue

Portland, Oregon 97201

http://or.water.usgs.gov 
